\title{
The lack of protection for juvenile sex offenders in South African law: a critical analysis of Section 50(2) of the Criminal Law (Sexual Offences and Related Matters) Amendment, Act 32 of 2007 and Section 18 of the Criminal Procedure, Act 51 of 1977
}

\author{
Danielle de Bruyn* \\ $L L B$ LLM \\ Candidate Attorney at Weavind \& Weavind Inc.
}

\section{OPSOMMING}

Die gebrek aan beskerming vir minderjarige seksuele oortreders in die SuidAfrikaanse eg: ' $n$ kritiese analise van Artikel 50(2) van die Wysigingswet op die Strafreg (Seksuele Misdrywe en Verwante Aangeleenthede, Wet 32 van 2007 en Artikel 18 van die Strafproseswet, Wet 51 van 197

\begin{abstract}
Die onlangse uitspraak deur die Suid-Gauteng Hooggeregshof in verband met artikel 18 van die Strafproseswet aangaande seksuele misdade teen beide volwasse- en jeugdige slagoffers, en gevolglik moontlik ook indirek, seksuele misdade deur beide volwasse- en jeugdige oortreders; asook die Konstitusionele Hof uitspraak ten opsigte van die Nasionale Register vir Seksuele Oortreders, wat spesifiek betrekking het op artikel 50(2) van die Wysigingswet op die Strafreg (Seksuele Misdrywe en Verwante Aangeleenthede), laat die vraag ontstaan of die Suid-Afrikaanse regsisteem enige vorm van beskerming bied aan minderjarige seksoortreeders? Hierdie artikel ondersoek twee spesifieke bepalings in Suid-Afrikaanse wetgewing met betrekking tot die grondwetlikheid en toepassing daarvan op minderjarige seksoortreders, naamlik artikel 50(2) van die Wysigingswet op die Strafreg (Seksuele Misdrywe en Verwante Aangeleenthede), asook artikel 18 van die Strafproseswet. Hierdie twee bepalings word ingevolge onlangse regspraak oorweeg om vas te stel of dit 'n skending is van die regte wat minderjarige seksuele oortreders het ingevolge die SuidAfrikaanse reg.
\end{abstract}

\section{Introduction}

The recent judgment passed down by the South Gauteng High Court with regard to section 18 of the Criminal Procedure Act 51 of 1977 (CPA) pertaining to sexual crimes committed against both adult and juvenile victims and, thus indirectly, crimes committed by both adult and juvenile

* This article is derived from my LLB dissertation prepared under the supervision of Professor PA Carstens during the completion of my LLM. I have updated it insofar as there have been new developments in the law since the submission of the dissertation in 2014. How to cite: De Bruyn'The lack of protection for juvenile sex offenders in South African law: a critical analysis
of Section 50(2) of the Criminal Law (Sexual Offences and Related Matters) Amendment, Act 32 of 2007 and Section 18 of the Criminal Procedure, Act 51 of 1977 ' 2018 De Jure 65-81 http://dx.doi.org/10.17159/2225-7160/2018/v51n1a5 
sex offenders, ${ }^{1}$ as well as the Constitutional Court judgment in relation to the National Register for Sex Offenders ${ }^{2}$ pertaining specifically to section 50(2) of the Criminal Law (Sexual Offences and Related Matters) Amendment Act 32 of 2007 (SORMA), highlights the question whether South African law affords any form of protection to juvenile sex offenders.

Consider the following scenario. Marc, a ten-year-old boy and Sally, his next-door neighbour, who is nine years old, decide to play 'doctordoctor'. ${ }^{3}$ During their play Marc inspects Sally's entire body in order to determine what 'disease' she has. ${ }^{4}$ In the course of the 'examination' Sally's mother walks into the playroom and is faced with Sally naked on the floor and Marc 'examining' and touching Sally's body. ${ }^{5}$

In terms of the SORMA Marc's conduct amounts to a 'sexual offence' due to the fact that the Act is extremely broadly defined and includes everything from rape to kissing. ${ }^{6}$ The ten-year-old juvenile will now be placed on the National Register for Sex Offenders ('the Register') in compliance with section 50(2) of the SORMA, which demands that the presiding officer enter the individual's (adult or child's) details into the Register. In addition to this and in light of section 18 of the CPA recently being declared unconstitutional, ${ }^{8}$ criminal proceedings can now be instituted against Marc at any time in the future, as the prescription period of twenty years in relation to the institution of criminal proceedings, provided for in terms of this section, no longer finds application to sexual offences. ${ }^{9}$ Does this account amount to a reasonable and justifiable form of punishment in relation to the scenario at hand? Is it fair and just to place an adolescent's details on a Register that has consequences that last for the rest of their lives?

1 L v Frankel (29573/2016) [2017] ZAGPJHC 140 (15 June 2017) - own emphasis added.

$2 J v$ NDPP (2014) ZACC 13

3 The term 'playing doctor/doctor-doctor' is used to describe children's exploration of one another's body, specifically one another's genitals. It is important to note that such conduct is deemed normal (as part of growing up) by child psychologists - Harris \& Emberley It's Perfectly Normal: Changing Bodies, Growing up, Sex and Sexual Health (1994).

4 De Bruyn The Constitutionality of placing a juvenile on the National Register for Sex Offenders (LLB dissertation 2014 UP) 1.

5 De Bruyn supra $\mathrm{n} 4$ at 1.

$6 J v$ NDPP supra n2 at par 79 - the amicus curiae argued that the section in the SORMA defining sexual conduct is too wide.

7 S 50(2)(a) of the Criminal Law (Sexual Offences and Related Matters) Amendment Act 32 of 2007 reads as follows:

'A court that has in terms of this Act or any other law - (i) convicted a person of a sexual offence against a child or a person who is mentally disabled ... must make an order that the particulars of the person be included in the Register [own emphasis added]'.

8 See $L v$ Frankel supra 1.

9 The decision of the South Gauteng High Court in L $v$ Frankel supra n1, is subject to approval from the Constitutional Court in line with s 172(2)(a) of the Constitution of the Republic of South Africa, 1996 (hereafter the Constitution). 
This article investigates two specific provisions in South African legislation pertaining to the constitutionality and application to juvenile sex offenders, namely section 50(2) of the SORMA and section 18 of the $\mathrm{CPA}$. These provisions are considered in terms of case law, to determine if these sections in fact are an infringement of the rights child sex offenders have in terms of South African law.

\section{The National Register for Sex Offenders}

In order to critically analyse section 50(2) of the SORMA, the foundation of this provision must first be discussed. The main provision that is disputed in regard to juveniles being placed on the Register is section 50 (2) of the SORMA. This section provides for a peremptory provision, namely that the presiding officer must place a sex offender's name on the Register. ${ }^{10}$ The National Register for Sex Offenders is provided for and incorporated in Chapter Six of the SORMA. The main purpose of the Register is to protect children and mentally disabled people against sexual offenders or alleged sexual offenders. ${ }^{11}$ This section continues to say that the way the legislature seeks to achieve this purpose is by establishing and maintaining a record of these sexual offenders. ${ }^{12}$

\section{Objective of the Register}

The purpose of the Register is to prohibit sex offenders in terms of the SORMA $^{13}$ from supervising, accessing or working with children or any mentally disabled person. ${ }^{4}$ Section 43 (b) of the SORMA ${ }^{15}$ provides for the second objective of the Register, namely that there is a duty accompanying the existence of the Register for the employer of a sex offender to be informed of the offender's particulars appearing in the Register as soon as the employer applies for a certificate. ${ }^{16}$ This duty comes into operation in regard to the following employment opportunities, namely the fostering, kinship, care, temporary safe-care, adoption or curatorship of any child or person that is mentally disabled. $^{17}$

10 S 50(2)(a) of the SORMA - own emphasis added.

11 S 43 of the SORMA outlines the objects of the Register.

12 S 43(a) of the SORMA.

13 S 43 of the SORMA.

14 Jooma The National Register for Sexual Offenders: The Solution to Protecting Children in South Africa? (LLM dissertation 2010 UP) 5; Vlotman The Constitutionality and Justification of the National Register for Sex Offenders (LLM dissertation 2010 UP) 1.

15 S 43(b) of the SORMA.

16 S 44 of the SORMA - the inquiry is initiated by the employer of the sexual offender by way of applying for a prescribed certificate which clearly indicates if the details of the person are recorded on the Register or not.

17 S 43(d) of the SORMA. 


\section{Section 50(2) of the Criminal Law (Sexual Offences and Related Matters) Amendment Act ${ }^{18}$}

Section 50(2) of the SORMA places an obligation on the presiding officer to enter the details of all sexual offenders into the Register. ${ }^{19}$ This obligation thus establishes a duty on the presiding officer and eradicates any form of discretion that the presiding officer has in terms of the circumstances of the case at hand.

When examining the contents and more specifically the wording of the SORMA, in relation to the Register, the term 'person' is used by the Legislature to refer to who must be placed on the Register by the presiding officer in terms of section 50(1) and (2) of the SORMA. ${ }^{20}$ The word 'person' has sparked much debate in South African law with regard to whether this entails the inclusion of children in the ambit of the Act. ${ }^{21}$ Upon closer inspection of the wording of Chapter Six of the SORMA, it becomes evident that no reference is made to 'child offender', reference is merely made to 'person'. ${ }^{22}$ Therefore it is clear that the intention of the legislature was for the ambit of the Register to include both adult and juvenile offenders - without taking into consideration the impact of such an intention. 23

The confusion as to whether the word 'person' includes both adults and juveniles however was resolved in the case of $S \mathcal{V} R$; $S \mathcal{v} D K$ and Another, ${ }^{24}$ where the Northern Cape High Court took it upon itself to clarify the term 'person' in section 50(1) and (2) of the SORMA. ${ }^{25}$ The Court decided to opt for a strict meaning of the word 'person', therefore the dictionary meaning, and held that in applying this form of interpretation the term in fact includes juveniles. ${ }^{26}$ The Court went further, declaring if the legislature intended the application of the Register to be restricted to adult offenders, it would have stated it in a

1832 of 2007

19 S 50(2)(a) of the SORMA.

20 S 50(1)(a) of the SORMA reads as follows:

'A person who in terms of this Act or any other law...', and s 50(2)(a)(ii) reads as follows: '... must make an order that the particulars of the person be included in the Register'; Jooma supra $\mathrm{n} 14$ at 9.

21 See the discussion of $S$ v RB; S v DK 2010 (1) SACR 447; De Bruyn supra n4 at 16; Jooma supra n14 at 17.

22 De Bruyn supra n4 at 16.

23 Ibid.

$24 S v R B ; S v D K$ supra $\mathrm{n} 21$.

25 Jooma supra n14 at 17-18; Vlotman supra n14 at 18-19; see also Democratic Alliance $v$ Speaker of National Assembly [2016] ZACC 8 at par 19.

26 The Oxford English Dictionary defines the word 'person' to mean: 'A human being regarded as an individual'. It is evident from this definition that both adults and children qualify as human beings; In the Constitutional Court case of Cool Ideas 1186 CC v Hubbard [2014] ZACC 16 at par 28, the Court held the following when it comes to the statutory interpretation of a word: 'A fundamental tenet of statutory interpretation is that the words in a statute must be given their ordinary grammatical meaning, unless to do so would result in an absurdity. There are three important interrelated riders to 
clear and unambiguous way. ${ }^{27}$ This judgment however is subject to criticism, in the sense that the dictionary meaning of the word 'person' was too greatly relied on. Instead of considering the object of the legislation itself the Court focused mainly on the dictionary meaning of the word 'person' and also relied on the intention of the legislature to assist in the interpretation. ${ }^{28}$

In the case of Transvaal Consolidated Land and Exploration Co Ltd $v$ Johannesburg City Council ${ }^{29}$ the Court held the following with regard to dictionary meanings attached to words: 'Dictionary definitions serve to mark out the scope of the meanings available for a word, but the task remains of ascertaining the particular meaning and sense of the language intended in the context of the statute under consideration'. ${ }^{30}$ In De Beers Industrial Diamond Division (Pty) Ltd $v$ Ishizuka ${ }^{31}$ the Court expressly held that the dictionary definition cannot have the final say in the interpretation of a word. ${ }^{32}$

It must further be argued that an interpretation based on the 'intention' of the legislature also is not the preferred interpretation to be followed, hence the judgment in $S$ V RB; S v DK and Another ${ }^{33}$ can be further criticised. ${ }^{34}$ This type of interpretation was employed at a stage when the South African legal system still followed the principle of parliamentary sovereignty. Due to the supremacy of parliament, legislation had to reflect the underlying intention of the legislature. ${ }^{35}$ South Africa has adopted the approach which elevates the supremacy of the Constitution, therefore, an interpretation based on the underlying rights and values of the Constitution and the Bill of Rights is the preferred approach to interpret the word 'person'. 36 If the aforementioned interpretation were to be accepted, effect will have to be given to section $28(2)$ of the Constitution ${ }^{37}$ and the inclusion of children in the ambit of

this general principle, namely:

(a) that statutory provisions should always be interpreted purposively;

(b) the relevant statutory provision must be properly contextualised; and

(c) all statutes must be construed consistently with the Constitution, that is, where reasonably possible, legislative provisions ought to be interpreted to preserve their constitutional validity. This proviso to the general principle is closely related to the purposive approach referred to in (a)'.

27 De Bruyn supra n4 at 16.

28 Idem at 17.

29 Transvaal Consolidated Land and Exploration Co Ltd $v$ Johannesburg City Council 1972 (1) SA 88 (W).

30 Transvaal Consolidated Land and Exploration Co Ltd $v$ Johannesburg City Council supra n29 at 94G; Botha Statutory Interpretation: An Introduction for Students (2005) 86.

311980 (2) SA 191 (T).

32 Botha supra n30 at 86.

33 S V RB; S v DK supra n21.

34 De Bruyn supra n4 at 17.

35 Botha supra n30 at 66.

36 Idem 52-58; Investigating Directorate: Serious Economic Offences v Hyundai Motor Distributors (Pty) Ltd In re: Hyundai Motor Distributors (Pty) Ltd v Smit [2000] ZACC 12 at par 23.

37 The best interest of the child principle. 
the Register would be deemed unconstitutional if the best interest of the child were to be disregarded. ${ }^{38}$

\section{$23 \mathrm{~J}$ v National Director of Public Prosecutions ${ }^{39}$}

The importance of this case lies in the fact that the Court considered whether it is explicitly unconstitutional for the details of a juvenile sex offender to be entered into the Register or whether it is merely unconstitutional for the discretionary powers of the presiding officers to be restricted by section 50(2) of the SORMA because the details of adolescent offenders are included automatically, without assessing each case on its own merits. ${ }^{40}$

The provision that was challenged and finally brought under constitutional scrutiny was section 50(2) of the SORMA. In the High Court case of $S$ V IJ ${ }^{41}$ the court ruled this provision to be unconstitutional, in the sense that it is a peremptory provision which must be amended to a discretionary one. ${ }^{42}$

The facts briefly are as follows. ${ }^{43} \mathrm{~J}$, a fourteen year old juvenile, ${ }^{44}$ was charged with contravening section 3 of the SORMA ${ }^{45}$ on account of raping three minors. ${ }^{46}$ In addition to these charges, J was charged with assault with intent to cause grievous bodily harm, as furthermore he stabbed a girl who was twelve years old at the time. ${ }^{47} \mathrm{~J}$ appeared in a Child Justice Court ${ }^{48}$ where he pleaded guilty to all the aforementioned charges and was convicted and thereafter sentenced to a Child and Youth Care Centre for a period of five years. ${ }^{49}$ Upon completion of his residence at this Centre he was required to complete a three-year imprisonment sentence on account of the three rape charges. ${ }^{50}$ In addition to the sentence imposed on $\mathrm{J}$, the presiding officer in the Child Justice Court in compliance with section 50(2) of the SORMA, made the

38 De Bruyn supra $\mathrm{n} 4$ at 18.

$39 J v$ NDPP supra n2.

40 De Bruyn supra n4 at 2.

41 S v IJ 2013 (2) SACR 599 (WCC).

$42 S \mathcal{V}$ IJ supra n41 at par $93 \& 136$; De Bruyn supra $\mathrm{n} 4$ at 26.

43 S v IJ supra n41 at par 2-8; De Bruyn supra n4 at 24-25.

44 The Applicant in the High Court case.

$45 \mathrm{~S} 3$ of the SORMA - this section specifically provides for rape, and reads as follows: 'Any person ('A') who unlawfully and intentionally commits an act of sexual penetration with a complainant ('B'), without the consent of $\mathrm{B}$, is guilty of the offence of rape'.

46 S v IJ supra $\mathrm{n} 41$ at par 2.

$47 \quad S v$ IJ supra n41 at par 3.

48 As provided for in the Child Justice Act 75 of 2008 s 24.

49 S v IJ supra n41 at par 4.

$50 J \mathcal{V} N D P P$ supra $\mathrm{n} 2$ at par 3 - The sentence was imposed based on sec 76(1) and (3) of the CJA. 
order for J's details to be entered into the National Register for Sex Offenders. ${ }^{51}$

Counsel on behalf of J argued that section 50(2) of the SORMA awards no discretion to the presiding officer deciding the case of a child offender. ${ }^{52}$ Instead, this peremptory provision forces the judge to enter the details of the offender into the Register by default. It was further argued that placing juvenile offenders on the Register infringes multiple constitutionally entrenched rights of the juvenile, ${ }^{53}$ specifically sections $10,{ }^{54} 14^{55}$ and $28(2)$ of the Constitution. ${ }^{56}$ Additionally, it was argued that entering the details of a juvenile into the Register serves no purpose - the long-term consequences of the Register are aimed at the actions of an adult offender and including children within the ambit of the Register does not correspond to the purpose and objects of the Child Justice Act (CJA). ${ }^{57}$

The Court not only held that section 50(2) of the SORMA infringes the rights of child offenders, but to some extent the rights of adult offenders as well. Entering the details of a person (adult or juvenile) into the Register has a dire effect on each individual's right to be heard. ${ }^{58}$ Section 50 (2) disallows the offender (whether it is an adult or child) to provide the court with reasons (make representations) why his/her details should not be entered into the Register. ${ }^{59}$ The High Court thus declared section 50(2) of the SORMA unconstitutional, based on the aforementioned arguments, as well as on the lack of application of the audi et alteram partem rule. ${ }^{60}$

This ruling was sent to the Constitutional Court for confirmation. ${ }^{61}$ Three issues had to be considered by the Constitutional Court: ${ }^{62}$ First, whether adult offenders should be included within the ambit of the decision of S V IJ; ${ }^{63}$ second, whether section 50(2) of the SORMA has the effect of limiting constitutional rights and, if it does, is such a limitation

51 S 50(2)(a) of the SORMA reads as follows: 'A court that has in terms of this Act or any other law - (i) convicted a person of a sexual offence against a child or a person who is mentally disabled ... must make an order that the particulars of the person be included in the Register [own emphasis added]'

52 S $v$ IJ supra n41 at par 53

53 Idem at par 70.

54 Right to dignity.

55 Right to privacy.

56 S 28(2) reads as follows: 'A child's best interests are of paramount importance in every matter concerning the child'.

57 S v IJ supra n41 at par 98.

$58 \mathrm{~S} 34$ of the Constitution - Audi et alteram partem rule.

59 S v IJ supra n41 at par 126

60 S v IJ supra n41 at par 126.

$61 \mathrm{~S} 172(2)(\mathrm{a})$ of the Constitution provides that any order relating to constitutional invalidity must be confirmed by the highest court in the country, before it will come into force.

62 Z Hansungule 'The Automatic Inclusion of Child Offenders on the National Register for Sex Offenders $-J v$ National Director of Public Prosecutions and Another' 2014 (Forthwith Unpublished) 5.

63 S v IJ supra n41. 
justifiable? ${ }^{64}$ Lastly, based on the aforementioned consideration, if it is found that the limitation is unjustifiable in terms of section 36 of the Constitution, it must be declared unconstitutional and accordingly the Constitutional Court must provide a just and equitable solution. ${ }^{65}$

With regard to the first issue, the Constitutional Court held that whenever faced with the rights of a child, regard should be given to section 28(2) of the Constitution, namely the 'best interests of the child' principle. ${ }^{66}$ The Court confirmed that this principle is the starting point in all cases regarding children. ${ }^{67}$ As a result of the importance attached to this constitutionally entrenched principle, the Court construed three guiding principles when applying the 'best interests of the child' principle. ${ }^{68}$ First, the Court held that a general distinction between adults and children should be established in law. ${ }^{69}$ Second, the Court held that the law as we know it should make provision for an individuated methodology when dealing with child offenders. ${ }^{70}$ Third, the Court reiterated the High Court judgment in saying that a child offender should be given the opportunity to be heard throughout the entire criminal justice process, taking into consideration both the maturity and the age of the juvenile. 71

In relation to the second issue; namely whether such a limitation of the rights of the child offender would be justifiable, the Court held that section 28(2) of the Constitution is subject to limitation as found in the limitation clause, which states that rights in the Bill of Rights are subject to limitation. ${ }^{72}$ The Court however held that taking the factors mentioned in section 36 into account there are less restrictive means to achieve the same purpose or outcome that the Register seeks to achieve. ${ }^{73}$ The argument was advanced that if section 50(2) of the SORMA were to be amended to a discretionary provision, which allows the offender an opportunity to make representations and the presiding officer to decide each case on its own merits, it would ensure a better relationship (correlation) between the limitation and its purpose. ${ }^{74}$

64 In terms of s 36 of the Constitution - The Limitation Clause.

$65 J v N D P P$ supra $\mathrm{n} 2$ at par 7.

66 Idem at par 35.

$67 J v N D P P$ supra $\mathrm{n} 2$ at par 35; De Bruyn supra $\mathrm{n} 4$ at 38 - The Court in $S v M$ 2007 (2) SACR 539 (CC) provided us with a realistic approach to this principle by not affording s 28(2) dominance over all other constitutionally entrenched rights, but reaffirming and balancing the importance attached to the provision, hence the importance afforded to any matter involving a juvenile.

$68 J v$ NDPP supra n2 at par 37-40.

69 Here the court confirmed the need for separate sentencing options for children and adults, hence the CPA for adult offenders and the CJA for juvenile offenders.

70 The enactment of the CJA reflects this principle.

$71 J v$ NDPP supra n2 at par 40.

$72 \mathrm{~S} 36$ of the Constitution.

$73 \mathrm{~S} 36(\mathrm{e})$ of the Constitution.

$74 J v$ NDPP supra $\mathrm{n} 2$ at par 50. 
Finally, the Constitutional Court came to the conclusion that limiting section 50(2)(a) of the SORMA, pertaining to child offenders specifically, is not justifiable in an open and democratic society. ${ }^{75}$ Hence this provision was declared unconstitutional to the extent that it requires the details of child offenders to be entered into the Register automatically. Due to the failure of evidence being introduced to prove that harm will not be done to children and/or mentally disabled persons, no moratorium on the placement of child offenders on the Register could be ordered, and no pronouncement could be made as to the retrospectivity of the ruling. The Court employed the remedy of awarding the legislature fifteen months to amend the defect, during which time the pronouncement was accordingly suspended. ${ }^{76}$

\section{A critical analysis of $J v$ National Director of Public Prosecutions $^{77}$}

The judgment handed down by the Constitutional Court is a good starting point in realising that child sex offenders in fact are children and thus the same rights that apply to and protect child victims should apply mutatis mutandis to every child in South Africa, including child offenders. ${ }^{78}$ Child offenders have the right to be heard, ${ }^{79}$ the right to human dignity, ${ }^{80}$ the right to privacy ${ }^{81}$ and, most importantly, the 'best interests of the child' principle, ${ }^{82}$ which is just as applicable to juvenile offenders as to any other child in the Republic, irrespective of the fact that they are offenders. ${ }^{83}$

The Court, in $J \mathcal{V} N D P P,{ }^{84}$ expressly acknowledged the aforementioned, but this article takes the view that this acknowledgement however is not enough. The Constitutional Court did not go far enough in its judgment in awarding the presiding officer a discretionary power in terms of section $50(2)$ of the SORMA. ${ }^{85}$ Instead of making the provision a discretionary one with reference to adolescent sex offenders the Court should have realised that the judgment still infringes the rights of juvenile offenders because in actual fact it only replaced one word with another in section 50(2) of the SORMA. ${ }^{86}$

The suggestion made in this article is that the Court rather should have interpreted the word 'person' as found in sec 50(2), instead of replacing

75 S 36 of the Constitution '... based on human dignity, equality and freedom ....

$76 J v$ NDPP supra $\mathrm{n} 2$ at par 56.

77 Jv NDPP supra $\mathrm{n} 2$.

78 De Bruyn supra 44 at 30.

79 S 34 of the Constitution.

$80 \mathrm{~S} 10$ of the Constitution.

81 S 14 of the Constitution.

82 S 28(2) of the Constitution.

83 De Bruyn supra $\mathrm{n} 4$ at 30.

$84 J v$ NDPP supra n2.

85 De Bruyn supra n4 at 30.

86 Ibid. 
one word with another. ${ }^{87}$ Such an interpretation would be restrictive, such as to exclude juvenile sexual offenders from the ambit and scope of the Register. ${ }^{88}$ In addition to a restrictive interpretation of the word 'person', an interpretation in light of the values and notions underpinning the Constitution should have been adopted, which would have led to the exclusion of children from the ambit in order to give effect to the best interests of children, as demanded by sec 28(2) of the Constitution. ${ }^{89}$

\section{Prescription of the right to institution of prosecution}

\section{The Development of Section 18 of the Criminal Procedure Act ${ }^{90}$}

In order to understand the recent South Gauteng High Court judgment passed down by Acting Judge Claire Hartford, on the constitutionality of section 18 of the CPA, the progression and development of this section from 1977 to 2007 needs to be addressed. ${ }^{91}$

Section 18 of the CPA provides for a prescription period attached to the right to institute criminal proceedings. Thus, according to this section, should the crime not fall within the list of excluded crimes set out in this section, the right to criminally prosecute someone lapses after a period of twenty years. ${ }^{92}$ An important factor about this section, which has been visible throughout its development, is the fact that the twentyyear prescription period is subject to a list of crimes that are excluded from this provision. Thus, for example, the prescription period does not find application to the crime of murder. ${ }^{93}$ The expansion and adjustment of the list of excluded crimes however led to the development and progression of section 18 over the last forty years.

What is important to note from the section as it stood in 1977 was that the list of excluded crimes was determined by crimes susceptible to the imposition of the death penalty as the form of punishment. ${ }^{94}$ Then, in 1997, after the case of $S v$ Makwanyane ${ }^{95}$ the death penalty was declared

87 De Bruyn supra $\mathrm{n} 4$ at 31.

88 Ibid.

89 Ibid.

90 Criminal Procedure Act 51 of 1977.

$91 \quad L v$ Frankel supra $\mathrm{n} 1$ at par 21.

$92 \mathrm{~S} 18(1)$ of the CPA.

93 As murder is included in the list of excluded crimes provided for in section 18 of the CPA.

94 In the 1977 Act, Section 18 read as follows: '18(1) The right to institute a prosecution for any offence, other than an offence in respect of which the sentence of death may be imposed, shall, unless some other period is expressly provided by law, lapse after the expiration of a period of twenty years from the time when the offence was committed:

95 S v Makwanyane 1995 (6) BCLR 665. 
unconstitutional, which called for section 18 to be amended in order to determine which crimes were to be exempted from the twenty-year prescription period. ${ }^{96}$ The legislature deemed it fit to amend the section by including a list of specific crimes it believed to be too serious to be susceptible to a prescription period. ${ }^{97}$

Following the enactment of the SORMA in 2007, section 18 of the CPA had to be amended once again as the definition of rape underwent extensive scrutiny and revision. ${ }^{98}$ Prior to the SORMA, the common law definition of rape was restricted to the non-consensual, vaginal sexual penetration of a female by a male. ${ }^{99}$ This definition therefore not only was restricted to vaginal penetration by a male sexual organ, but also was gender restrictive. According to the common law definition of rape a male could only rape a female, and therefore a male raping a male was not considered to be 'rape' in terms of this definition. The common law definition of rape was challenged in the case of Masiya $v$ Director of Public Prosecutions, Pretoria and Another (Centre for Applied Legal Studies and Another, Amici Curiae). ${ }^{100}$ In the aforementioned case the definition of rape was broadened to include anal penetration by males of females, ${ }^{101}$ but still did not provide for a gender neutral definition of rape as the Court held such a decision would intrude on the principle of legality. ${ }^{102}$ Subsequent to this ground-breaking Constitutional Court decision the definition of rape was still flawed as it did not provide for gender neutrality. The legislature needed to address the issue of gender neutrality, which it did with the enactment of the SORMA in 2007. As a result of the amendment of the definition the term 'rape' now includes all forms of sexual penetration and the crime can be committed by and against males and females. ${ }^{103}$ As a result of the extension of this

96 At this time, in 1997, section 18 of the CPA thus read as follows:

'18. The right to institute a prosecution for any offence. other than the offences of -

(a) murder;

(b) treason committed when the Republic is in a state of war;

(c) robbery if aggravating circumstances were present;

(d) kidnapping;

(e) child-stealing; or

(f) rape,

shall. unless some other period is expressly provided by law. lapse after the expiration of a period of 20 years from the time when the offence was committed:

$97 L v$ Frankel supra $\mathrm{n} 1$ at par 24 - this list provided for six separate crimes to which the twenty-year prescription period (provided for in section 18) did not apply.

98 Idem at par 25.

99 Burchell Principles of criminal law (2013) 595; Snyman Criminal Law ((2008) 356See par 9 Masiya v Director of Public Prosecutions, Pretoria (Centre for Applied Legal Studies, Amici Curiae) 2007 (5) SA 30 (CC).

1002007 (5) SA 30 (CC).

101 Masiya $v$ Director of Public Prosecutions, Pretoria (Centre for Applied Legal Studies, Amici Curiae) supra n99 at par 74; Burchell supra n99 at 595.

102 Masiya $v$ Director of Public Prosecutions, Pretoria (Centre for Applied Legal Studies, Amici Curiae) supra n99 at par 30.

103 Burchell supra n99 at 601-602. 
definition an amendment to section 18 of the CPA in $2007^{104}$ led to a few extra crimes being added to the list of crimes exempted from the prescription period. ${ }^{105}$

\section{L and Others v Frankel and Others ${ }^{106}$}

Following the amendment of section 18, twice already since the enactment of the CPA in 1977, the last in 2007 and each amendment being ten years apart, it made sense that 2017 should bring about yet another (possible) amendment to this provision. The question asked is how can one possibly still amend this section?

The facts of the court case, which may lead to the third amendment of section 18 of the CPA, are as follows. ${ }^{107}$ The Applicants accused the First Respondent (hereafter referred to as 'Frankel') of having 'indecently and/ or sexually assaulted' them between 1970 and 1989. ${ }^{108}$ The Applicants, both female and male, were between the ages of six and fifteen years old at the time the alleged crimes were committed. ${ }^{109}$ Only between 2012 and 2015 did the Applicants finally seek a criminal prosecution of Frankel for the acts committed against them some thirty odd years ago. ${ }^{110}$ The Court (rightly so) however informed the Applicants that according to the twenty-year prescription period provided for in section

104 Currently, section 18 reads as follows:

'18 Prescription of right to institute prosecution

The right to institute a prosecution for any offence, other than the offences of-

(a) murder;

(b) treason committed when the Republic is in a state of war;

(c) robbery, if aggravating circumstances were present;

(d) kidnapping;

(e) child-stealing;

(g) the crime of genocide, crimes against humanity and war crimes, as contemplated in section 4 of the Implementation of the Rome Statute of the International Criminal Court Act, 2002; or

(h) trafficking in persons for sexual purposes by a person as contemplated in section 71(1) or (2) of the Criminal Law (Sexual Offences and Related Matters) Amendment Act, 2007; or

(i) using a child or person who is mentally disabled for pornographic purposes as contemplated in sections 20(1) and 26(1) of the Criminal Law (Sexual Offences and Related Matters) Amendment Act, 2007, shall, unless some other period is expressly provided for by law, lapse after the expiration of a period of 20 years from the time when the offence was committed.

(f) rape or compelled rape as contemplated in sections 3 or 4 of the Criminal Law (Sexual Offences and Related Matters) Amendment Act, 2007, respectively;'

105 L v Frankel supra $\mathrm{n} 1$ at par 25 - a total of nine crimes now form part of the list of excluded crimes found in s 18 of the CPA.

106 L v Frankel supra $\mathrm{n} 1$.

107 The amendment of s 18 of the CPA as expressed in L $v$ Frankel supra $\mathrm{n} 1$, is subject to confirmation by the Constitutional Court, see supra $\mathrm{n} 10$.

108 The definition of rape at this time was still extremely narrow and, for example, did not include any form of penetration by a male in terms of an adolescent (or adult) male.

$109 L v$ Frankel supra n1 at par 13 - the reason provided to the Court by the Applicants for only seeking justice so long after the commission of the acts were that they only now acquired: 'full appreciation of the criminal acts committed by the first respondent'.

110 L v Frankel supra n1 at par 14. 
18 of the CPA (in its current form), their claims are prescribed and they could no longer seek a criminal prosecution against Frankel. ${ }^{11}$ The reason for this is that the acts committed by Frankel, during that time, merely amounted to indecent assault and/or sexual assault, as the definition of rape, as it stood then, was extremely narrow and his acts did not fall within the ambit of this definition. ${ }^{112}$ Thus, according to section 18, the crimes committed by Frankel (at that time) did not fall within the list of excluded crimes and hence the twenty-year prescription period finds application.

The Applicants applied to have section 18 of the CPA declared unconstitutional and thus invalid ${ }^{113}$ based on the fact that the provision does not provide for a discretionary power regarding whether prosecution may be instituted or not, ${ }^{114}$ and secondly, that omitting to include all sexual offences (not merely rape and compelled rape) in the list of crimes exempted from prescription, infringes on their constitutionally entrenched rights to human dignity, ${ }^{15}$ equality, ${ }^{116}$ access to courts ${ }^{117}$ and the right to a fair trial, ${ }^{18}$ to mention only a few. ${ }^{119}$ The main question before the Court, in terms of section 18 (f) of the CPA was thus whether:

[A] rational basis exists for excluding rape and compelled rape from the prescription period of 20 years but including all other sexual offences within that time limit? ${ }^{120}$

In finding section 18 unconstitutional and therefore invalid the Court held that this provision infringes on the right to human dignity of an

111 Ibid.

112 L v Frankel supra $n 1$ at par 16.

113 It must be mentioned that Frankel died of cancer before the commencement of the 2017 case against him.

114 L v Frankel supra $\mathrm{n} 1$ at par 18, 28-31 - the National Prosecuting Authority (NPA) has a discretionary power in terms of s 197(2) of the Constitution to institute criminal proceedings. The Applicants argued that s 18 of the CPA infringes on this discretionary power of the NPA in that it attaches a time period within which prosecution should be instituted and therefore the NPA's discretion is severely limited.

115 S 10 of the Constitution - the Applicants' argued that any form of sexual offence infringes on your right to human dignity, not merely the crime of rape - see $L v$ Frankel supra $n 1$ par 72-76. They further relied on the Constitutional Court case of $S v$ Makwanyane supra n95, where the Court held that the right to human dignity is one of the most important human rights - Lv Frankel supra $n 1$ par 73.

116 S 9 of the Constitution - the Applicants' submitted that s18 further infringes on one's right to equality in the sense that if a crime, which is not included in the list of excluded crimes, has been committed against the victim, then the crime is not 'harsh' enough and therefore the crime will be susceptible to the prescription period. Thus, a distinction is drawn between sexual offences based on the 'severity' of the sexual offence endured $-L v$ Frankel supra $\mathrm{n} 1$ at par 77-78.

117 S 34 of the Constitution.

118 S 35(3) of the Constitution.

119 L $v$ Frankel supra $n 1$ at par 17-18.

120 Idem at par 46. 
individual in that sexual offences other than rape and compelled rape infringes one's human dignity as much and to the same extent as rape does. ${ }^{21}$ The Court further held section 9 of the Constitution, namely the right to equality, is also infringed by the current section 18 of the CPA in that a distinction is drawn between sexual offences based on the severity of the offence. ${ }^{122}$ The Court held that no prescription period exists for rape and compelled rape, but the twenty-year prescription period exists for other sexual offences, and so the law discriminates against victims who had to endure a 'less serious' sexual offence than rape or compelled rape. $^{123}$ In considering whether section 18 infringes on the constitutionally entrenched right to a fair trial, the Court had to conduct a balancing act between the rights of the victims and the rights of the accused. ${ }^{124}$ The Court held that the offender would not be more greatly prejudiced should all sexual offences be included in the list of excluded crimes together with rape and compelled rape. ${ }^{125}$ In declaring section 18 inconsistent with the Constitution and invalid, the Court held that section 18 (in its current form):

[b]ars, in all circumstances, the right to institute a prosecution for sexual offences, other than those listed in section 18(f), (h) and (i), after the lapse of a period of 20 years from the time the offence was committed. ${ }^{126}$

In addition to the above order the Court further suspended the aforementioned order as to constitutional invalidity for a period of eighteen months in order to afford parliament the opportunity to remedy the constitutional invalidity/defect. ${ }^{127}$ The aforementioned order automatically raises the question of retrospectivity and whether the order granted by Hartford AJ with regard to sexual offences in terms of section 18 have retrospective effect. In determining whether the order should have retrospective effect, the Court once again implemented a balancing act, and held that such a balancing act would fall in favour of retrospectivity. ${ }^{128}$

In terms of the second order granted, namely the suspension for eighteen months of the main (first) order, the issue as to a possible interim relief/remedy was raised. ${ }^{129}$ The interim relief considered and finally implemented by the Court was that of reading in, hence the third order granted, namely; subject to parliament rectifying the content of section 18 to be in line with the Constitution, alternatively the lapse of the eighteen-month period referred to in order two above, whichever of the two is the soonest, section 18(f) of the CPA would include the following words 'and all other sexual offences, whether in terms of

121 Idem at par 47

122 Idem at par 78.

123 Idem at par 78-79.

124 Idem at par 80.

125 Idem at par 83.

$126 L v$ Frankel supra $\mathrm{n} 1$ - see point number one in the Order.

127 L v Frankel supra $\mathrm{n} 1$ - see point number two in the Order.

$128 L v$ Frankel supra $\mathrm{n} 1$ par 91.

129 Idem at par 107 
common law or statute' after the words 'the Criminal Law (Sexual Offences and Related Matters) Amendment Act, 2007, respectively’. ${ }^{130}$

\section{A critical analysis of $L$ and Others $v$ Frankel and Others $^{131}$}

The fact that this judgment speaks to the constitutionality of section 18 and affords parliament eighteen months to remedy the unconstitutionality of the provision, but, more specifically, provides for interim relief in the form of reading words into the current provision, has far-reaching consequences as to the implication of the orders granted.

It must be mentioned that this critical discussion of the judgment relates solely to its (possible) application to child sex offenders, as its implication in relation to adult sex offenders is a victory long-awaited in South African law.

If the amended section 18 of the CPA is ruled to be applicable to sexual offences committed by both adult and juvenile sex offenders, the purpose of the legislature, which saw the need for individual legislation governing the sentencing as pertaining to adult and juvenile offenders respectively, would be disregarded. ${ }^{132}$ The aims of the CPA and the CJA are divergent. The CPA aims to enforce justice through punishment and retribution, ${ }^{133}$ whereas the CJA focuses on rehabilitation and restorative justice. ${ }^{134}$ Declaring the twenty year prescription period in relation to all sexual offences committed by adult sex offenders unconstitutional aligns with the purpose of the CPA, namely the enforcement of justice through punishment and retribution, but demolishing this prescription period for sexual crimes committed by juvenile sex offenders does not accord with the purpose and objectives of the CJA and cannot be said to promote rehabilitation and restorative justice. ${ }^{135}$

The fact that all sexual offences are now included in the list of excluded crimes found in section 18 of the CPA, means that the wide definition of a 'sexual offence' as provided for in the SORMA will lead to juveniles being placed on the Register for actions as 'innocent' as those of Marc. Not only will their details be entered into the Register with consequences lasting their entire lives, but now, if the amendment of section 18 finds application to juvenile sex offenders, the actions committed by these juveniles when they were still in their developmental phase ${ }^{136}$ will result in the possibility of criminal proceedings being instituted when they attain adulthood, though these experimental actions

$130 L v$ Frankel supra $\mathrm{n} 1$ - see point number three in the Order for.

131 L $v$ Frankel supra $\mathrm{n} 1$.

132 De Bruyn supra n4 at 34.

133 Idem 35.

$134 \mathrm{~S} 2$ of the CJA, namely 'Objects of Act'.

135 Idem 48-50.

136 In par 60 of the amicus curiae's Heads of Argument in $J v$ NDPP (2014) ZACC 13 Skelton explains that research showed child offenders, due to their 
from their childhood might have been simply that 'experimental'. ${ }^{137}$ In terms of the amended section 18 of the CPA, Marc can be criminally prosecuted for the actions he committed as a child at any time in the future.

\section{Conclusion}

When one considers the terms; 'sex offender', 138 'paedophile,139 and 'sexual predator', ${ }^{140}$ the connotations of these terms do not depict the image of a child, who, like Marc, played 'doctor-doctor' ${ }^{141}$ with his nextdoor neighbour. It must be borne in mind that even though these juveniles are viewed as sex offenders who have committed a sexual offence against fellow minors, they cannot simply be treated as adults because they committed an act viewed as adult behaviour. ${ }^{142}$ The conduct committed by these child offenders does not reflect that their maturity levels, brain development, social skills or physical age correspond to those of adult sex offenders. ${ }^{143}$

What the legislature forgot in enacting the Register, together with the peremptory provision of section 50(2) of the SORMA, is the fact that the definition of a 'sexual offence' is extremely wide, ${ }^{144}$ leading to situations in which a child such as Marc enters into the sphere of the criminal justice system, whereas the use of an alternative form of punishment would have been more appropriate in the given circumstances. The main consequence of registration laws (entering a juvenile's particulars into the Register) is that they capture many juvenile offenders, such as Marc, who are not likely to re-offend, resulting in their details remaining on the Register. ${ }^{145}$

ongoing psychological development during their juvenile period, respond far better to treatment than adults do under the same circumstances; De Bruyn supra n4 at 40 .

137 There have been numerous long-and-short term clinical follow-up studies which demonstrate the fact that a large number (about 85 percent) of the child sex offenders have no further arrests or reports of other sexual offences committed - Finkelhor, Ormrod and Chaffin 'Juveniles Who Commit Sex Offenders Against Minors’ 2009 Juvenile Justice Bulletin 1; De Bruyn supra $\mathrm{n} 4$ at 40

138 The Oxford English Dictionary defines the word 'sex offender' as: 'A person who commits a crime involving a sexual act'.

139 The Oxford English Dictionary defines the word 'pedophile' as: 'A person who is sexually attracted to children'.

140 The Oxford English Dictionary defines the word 'sexual predator' as: 'A person who ruthlessly exploits others'.

141 The term 'playing doctor/doctor-doctor' is used to describe children's exploration of one another's body's, specifically one another's genitals See Harris \& Emberley supra n3.

142 De Bruyn supra n4 at 39.

143 Idem 39.

144 See par 57 of the amicus curiae's Heads of Argument in $J \mathcal{V}$ NDPP (2014) ZACC 13.

145 Carpenter 'Against Juvenile Sex Offender Registration’ 2013 Law Review 36. 
The same form of punishment given to an adult sex offender cannot be applied mutatis mutandis to a juvenile offender who is still in the process of development on multiple different levels, and whose behaviour, conduct and thought patterns are still subject to change and influence. ${ }^{146}$ A substantial number of these cases which deal with juvenile offenders who now enter the criminal justice system are crimes committed by minors who do not correspond to the image evoked by terms such as 'paedophile' and 'predator'. ${ }^{147}$ Therefore these juveniles get caught up in the criminal justice system intended for serious adult offenders due to the extremely wide interpretation and ambit of the SORMA in terms of the definition of a 'sexual offence'. The Register serves as an instrument of protection for both children and mentally disabled persons, but if it protects child victims on the one hand, it infringes on the rights and well-being of child offenders, such as Marc, on the other.

When one considers the implications of both section 50(2) of the SORMA, coupled with the recent declaration of the unconstitutionality of section 18 of the CPA, Marc's details not only will be placed on the Register for the rest of his life, but now the fact that Marc played 'doctordoctor' with Sally means that the sword of criminal prosecution hangs over Marc's head until the date of his death. What if you were held accountable your entire life for an act you committed as a child? ${ }^{148}$

146 De Bruyn supra n4 at 41.

147 Finkelhor, Ormrod \& Chaffin 2009 Juvenile Justice Bulletin supra n137 at 1.

148 Carpenter 2013 Law Review supra n145 at 1. 